\title{
Further Studies on Transmission of the Causal Agent of the Chlorotic-Streak Disease of Sugarcane
}

\author{
Julio Bird
}

\section{INTRODUCTION AND REVIEW OF THE LITERATURE}

Several investigators $(1,4,6,19,14)^{2}$ from different parts of the world have effected transmission of the causal agent of the chlorotic-streak disease of sugarcane by growing together diseased and healthy plants in jars containing nutrient solution. Evidence was presented by Bird, Cibes, and Tió (6) to prove that the transmission of the causal agent from diseased to healthy plants can be effected by circulation of the nutrient solution in the absence of direct root contact. These findings were recently confirmed by Abbott (1) in Louisiana and by Sturgess (17) in Australia. Boneta (7) observed in Puerto Rico high incidence of chlorotic streak in fields containing sugarcane seedlings. These fields were located in a high-rainfall valley near the town of. Gurabo. In one case it was observed that the symptoms developed almost simultaneously throughout a field of 6-month-old seedlings. Abbott (1) grew diseased and healthy plants together in soil with high moisture but obtained no transmission of the causal agent by this means. Antoine (4), working in Mauritius, obtained evidence indicative of soil transmission when a healthy cutting became diseased after it was planted in soil which had supported the growth of an affected plant. Transmission was also effected when a healthy, heat-treated cutting was transferred to unsterilized soil from a diseased area.

\section{OBJECTIVES}

The rapid development of chlorotic-streak disease in a moist field planted to sugarcane seedlings suggests not only that the spread of the causal agent is carried out by water but is also soil-borne. It was decided to undertake work in an effort to determine whether, under our conditions, the causal agent of chlorotic streak is transmitted through the soil.

It was also thought advisable to determine whether the causal agent could be transmitted by growing diseased and healthy plants together in water-drenched sand. The possibility of infecting healthy sugarcane plants by mechanical inoculation of their roots was also investigated. Another of

${ }^{1}$ Phytopathologist, Agricultural Experiment Station, University of Puerto Rico, Río Piedras, P.R. The writer is indebted to Héctor Cibes, Marco A. Tió, Frederick L. Wellman, and Jaime Gonzalez for their valuable help during the course of these studies.

${ }^{2}$ Italic numbers in parentheses refer to Literature Cited, p. 18. 
the writer's goals was to study the relation of the streak disease of Napier grass (Pennisetum purpureum Shumac) to the chlorotic-streak disease of sugarcane.

\section{TRANSMISSION STUDIES}

All of the sugarcane plants used in these studies were grown from oneeyed seedpieces of the highly susceptible variety $\mathrm{H}$. 328560 (fig. 1A). The healthy seedpieces were obtained from presumably disease-free areas, hotwater treated $\left(52.5^{\circ} \mathrm{C}\right.$. for 25 minutes), immediately cooled with tapwater and then submerged in a P.M.A. ${ }^{3}$ solution for 5 minutes. After these treatments, the seedpieces were planted in galvanized-steel or in wooden flats $\left(14^{\prime \prime} \times 20^{\prime \prime} \times 41 / 2^{\prime \prime}\right)$ containing white quartz sand. The flats as well as the sand had been previously steam-sterilized.

The one-eyed seedpieces from which the stock of diseased plants was obtained came from severely diseased field canes. These seedpieces were treated with P.M.A. only prior to planting in the sterilized white sand.

The heat treatment used in these studies is indeed a rigorous one, but it was resorted to as an added margin of safety, even though the standard hot-water treatment is adequate to destroy the causal agent in the seedpieces. Except for the soil-transmission trial carried out in the field all the tests described in this report were conducted in screened greenhouses. In addition, the plants maintained in the greenhouse were sprayed every 2 weeks alternately with Parathion and Endrin.

\section{TRANSMISSION THROUGH WATER-DRENCHED SAND}

Trials were carried out to determine whether the causal agent would spread from diseased to healthy sugarcane plants if these were grown together in sand with an excess of water. Six sand flats containing about 15 healthy plants each were transferred and placed side by side on a new Durotex ${ }^{4}$ greenhouse bench $\left(96^{\prime \prime} \times 48^{\prime \prime} \times 6^{\prime \prime}\right)$. Four flats, each containing about 10 diseased plants, were placed in the remaining space. A gap of about 6 inches was left between the flats containing the two groups of plants. Fertilizer (6-12-6) was sprinkled lightly on the sand flats at the beginning of the test and also later at the time the plants were cut back.

At first the bench was flooded daily and water was slowly lost through its seams but eventually sand as well as algae and mosses prevented water from seeping through. After some 6 weeks, water was applied only about once a week in order to keep the sand drenched. After 3 months growth all the plants were cut back and allowed to ratoon. Fifteen days after the cutback procedure was effected, most of the shoots produced by the previously

${ }^{3}$ Phenyl mercuric acetate, 1:1600.

4 Asbestos cement. 
healthy specimens were found to be diseased. A few ratoons were observed to be free from symptoms and these were located on the edge farthest from the area containing the disease-source plants.

After $41 / 2$ months all the shoots produced by the previously healthy plants were found to be diseased. Very few of the shoots produced by the originally diseased plants survived. Two flats containing 20 healthy plants and kept in the same greenhouse but on a separate bench remained healthy. The results of this test confirmed the findings of different investigators with respect to the role played by water in the spread of the chlorotic-streak disease. These results as well as those of previous tests indicate either that the agent causing this malady, or its vector, if any, is capable of being spread by water. Indications from these tests are also that if an aquatic vector exists it may be small enough to escape visual observation. If in this test as well as in previous tests conducted in nutrient solution in Puerto Rico a vector was involved, it must be not only small, but rather abundant under varying conditions, or else capable of remaining in the diseased seedpieces.

It is of interest to mention at this time that various species of nematodes ${ }^{5}$ (Diplogaster, Aphelencoides, Panagrolaimus, Rhabditis, and Eucephalobus) obtained from nutrient solution on which diseased canes were growing were used in extensive replicated inoculation studies covering a period of many months. The nematodes failed to induce disease on healthy plants to which they were transferred in great numbers. While this does not necessarily signify that nematodes are not associated with this disease it is, however, an indication that the nematode species mentioned are not involved in its causation or spread.

\section{TRANSMISSION THROUGH SOIL}

\section{Greenhouse Experiments Using Field Soil as Source of Causal Agent}

In the first test eight soil samples from around and beneath eight severely affected plants growing in the field were separately transferred to 10-inch pots. Four of these units were steam-sterilized while four were left undisturbed. A total of 16 plants, each about 8 inches in height, and which originated from healthy heat- and P.M.A.-treated one-eyed seedpieces, were distributed equally among the pots. The pots were then set on 8-inch porcelain pans and placed on two different flat, greenhouse benches according to treatment. The two benches were separated from each other by about 3 feet. Enough water to maintain the pans full to their brims was added daily to each pot.

The development of the plants growing in the unsterilized soil was

- Kindly isolated and identified by Dr. G. Steiner and associates. 


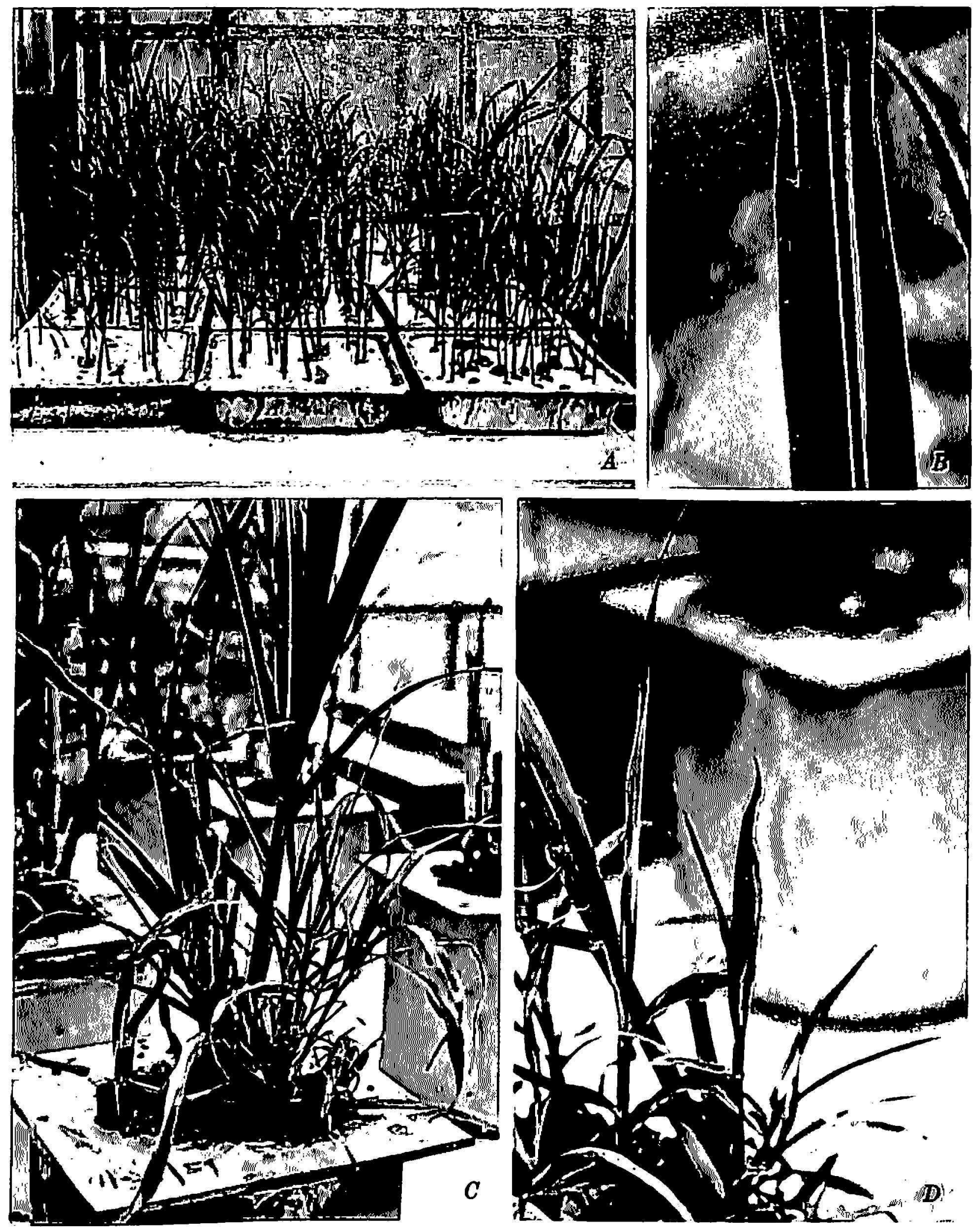

Fig. 1. - $A$, Healthy sugarcane plants of the variety H. 328560 growing on galvanized steel flats containing white quartz sand. $B$, Typical chlorotic streak on a leaf of a H. 328560 plant that contracted the disease when grown in soil from diseased areas. $C$, Napier grass and sugarcane plants growing together in jars containing nutrient solution. $D$, Initial symptoms of chlorotic streak on young sugarcane shoots growing together with affected Napier grass plants. 
stunted and their leaves were observed to be chlorotic about 3 weeks after transplanting. The healthy control plants in the sterilized soil grew visibly faster and their color was strikingly greener than that of the plants growing in the untreated soil. Two spoonfuls of 6-12-6 fertilizer were added to each one of the pots of both treatments 1 month after the onset of the test. Three months after the trial was commenced, two of the plants (mother plants) growing in a pot in the unsterilized soil, developed severe symptoms of chlorotic streak. At this time none of the plants growing in the untreated soil had produced secondary shoots, while all of those in the sterilized soil had.

A week after the primary symptoms were observed the treated and the control plants were cut back with separate pruning shears to about 4 inches from the soil level. Symptoms typical of the chlorotic-streak disease were evident 15 days later on six shoots that grew from the base of the two plants that first became affected (fig. 1B).

All the control plants remained healthy. A further control, consisting of hundreds of healthy stock plants which were kept in the same greenhouse where the study was being made, also failed to develop symptoms of the streak disease. The plants in the pots containing the undisturbed soil were pulled out and immediately replaced with 16 healthy plants at a rate of 4 per pot. The plants in the originally steamed soil were also replaced with healthy specimens. Five months elapsed and since no symptoms could be observed on any of the plants they were all cut back and allowed to ratoon. Thirty days after the canes were cut back symptoms of chlorotic streak developed on one shoot. On identifying the pot it was verified that it was the one where the earlier cases of disease had developed. The pots were maintained in the greenhouse for two more months and no further cases of chlorotic streak developed in either of the two treatments.

A more extensive test on soil transmission was effected using the same type of materials as well as procedure employed in the first phase of the previous trial. This time 60 healthy plants were equally distributed among 30 pots containing unsterilized soil from field sources. Another batch consisting of 100 healthy control plants was similarly distributed among new pots containing steam-sterilized soil from the same origin. Two months after the onset of the test one of the plants growing in a pot containing unsteamed soil from the field developed severe symptoms of chlorotic streak. Neither its companion plant nor the rest of the plants in both treatments had developed symptoms of chlorotic streak 3 months after the test was commenced. At this stage all the plants were cut back and shoots allowed to develop. One shoot that grew from the base of the affected cane as well as one that arose from the base of its companion plant, developed severe symptoms of chlorotic streak and then died. Two more cases of chlorotic 
streak appeared in two shoots belonging to two other different pot units in the unsterilized soil treatment. No instances of disease developed among the control plants. Many of the plants growing in the unsteamed soil produced ratoons which died before unfurling their leaves. The writer assumes that in all probability some of these would have developed chlorotic-streak symptoms had their growth progressed further. That this assumption is probably correct is evidenced by the results of the following test on the germinability of chlorotic-streak-affected seedpieces as compared with that of chlorotic-streak-free ones.

Presumably healthy as well as chlorotic-streak-affected canes obtained from the same general locality were placed in different burlap bags after being cut down to approximately 2 feet-long-pieces. The presumably healthy seedpieces were heat-treated $\left(52.5^{\circ} \mathrm{C}\right.$. for 25 minutes), cooled with tapwater, and placed on a greenhouse bench that was contiguous to one where the diseased seedpieces were kept. The affected as well as the healthy cane pieces were then cut down to one-eyed seedpiece size by two individuals and simultaneously immersed in different crocks containing P.M.A. solution (1:500). The solutions were decanted and the one-eyed seedpieces of both treatments separately planted in galvanized-steel flats containing steamed white quartz sand.

A total of 141 seedpieces was planted for each treatment. Approximately 82 percent of the healthy seedpieces produced shoots the leaves of which had unfurled at the end of 30 days while only 34 percent of the diseased seedpieces had done so after the same length of time. Forty-two of the diseased seedpieces produced roots at the root band and their eyes began to germinate, but this incipient growth became stunted and eventually the partly germinated buds died. It is possible, thus, that in the extensive test on soil transmission previously reported many cases of chlorotic streak went undetected because of premature death of the shoots due to the effects of the causal agent of chlorotic streak.

\section{Field Experiment}

An attempt was made to transmit the causal agent of the chlorotic-streak disease by growing affected and healthy sugarcane plants in alternate blocks in a gently sloped area in the field. The small plot $\left(20^{\prime} \times 36^{\prime}\right)$ used for this experiment had not been grown to sugarcane for at least 5 years. The experiment was arranged so that run-off rainwater would move by gravity through the alternate blocks of plants and finally come to rest on a diked section occupied by rows of healthy plants. A large number of healthy control plants was provided and grown above the alternate blocks, and separated from the slope by a buffer space of about 6 feet. This particular experiment was situated about 50 yards away from a commercial field 
where chlorotic streak was known to be extremely abundant and still spreading. All the plants in this test were allowed to grow undisturbed for 10 months at which time a disease count was made.

A single healthy test plant developed symptoms of chlorotic streak under the conditions of this test. This plant belonged to the first row of a block of healthy plants that was situated below a row of affected plants. Although the results were not significant from the standpoint of spread of the disease through the soil, they were nevertheless interesting if absence of aerial transmission is to be considered. If leafhoppers were at least partly involved in the transmission of chlorotic streak under our conditions more cases of disease should have resulted throughout the numerous healthy plants in this particular test. All the test plants were cut back at the 10th month of growth and allowed to ratoon. No other cases of disease were observed 6 months after the cut-back procedure was effected.

\section{TRANSMISSION OF CHLOROTIC STREAK FROM NAPIER GRASS TO SUgarCaNe PLANTS}

Napier grass is grown extensively in Puerto Rico for cattle feed. In 1953, Bruehl (8) described a streak disease of this grass and made observations on the similarity of that disease to the chlorotic-streak disease of sugarcane. Bruehl (8), and Bruehl and Boneta (9) were able to render Napier grass seedpieces free of the disease by treatment with hot water $\left(52^{\circ} \mathrm{C} . \times 20\right.$ minutes). The similarity of the symptoms of the disease on Napier grass to those on sugarcane, as well as the fact that the aforementioned heat treatment destroyed the causal agent in both hosts, prompted Bruehl and Boneta to postulate that this disease of Napier grass was caused by the same agent responsible for the streak disease of sugarcane.

A test using nutrient solution as a growing medium was made by the writer in an effort to transmit the causal agent from streak-diseased Napier grass to sugarcane plants. Sixteen Napier grass plants from a severely diseased field were taken to the greenhouse and their main stems pruned down to about 2 inches of height. The plants were washed several times with a jet of filtered water to free the roots from soil and were then set in pairs on 5-gallon aluminum-painted Pyrex crocks containing nutrient solution of the same type used in previous studies (6). The plants were also supported in the same manner as before (fig. $1 \mathrm{C}$ ). A total of eight jars, each containing two plants, was then set on a flat Durotex bench. Two days later, 16 sugarcane plants about 8 inches in height were obtained from the stock of healthy plants growing in the same greenhouse and were distributed equally among the jars where the diseased Napier plants were already growing. A control consisting of 16 healthy sugarcane plants growing in nutrient solution was set on a different bench in the same greenhouse. Again numerous 
healthy plants were maintained as control stock in the same greenhouse. The nutrient solution in the jars was replenished as needed and replaced every month.

Four months after the trial was set up, one of the sugarcane plants in one of the test units developed typical symptoms of chlorotic streak. At this stage all the plants were cut back and allowed to ratoon. Five and a half months after the test was started, transmission had been effected in four out of the eight test units. Nine sugarcane shoots out of a total of 22 produced by the test plants, developed symptoms of disease at this time. None of the controls or of the healthy-stock plants in the same greenhouse developed the malady. The symptoms on the test sugarcane plants in all cases were identical with those that are considered typical for the chloroticstreak disease of this host (fig. 1D).

\section{FAILURE OF TRANSMISSION BY MECHANICAL MEANS}

From the indications of all of our tests, as well as from the results reported by other investigators, the causal agent of the chlorotic-streak disease of sugarcane gains access to the plants through their root systems. Having this in mind, attempts were made to transfer the etiologic agent by inoculating the roots of healthy plants with extracts from roots of affected ones. The roots and lower parts of 16 small healthy plants were washed free of sand and the plants temporarily set in a sterilized, stainless-steel beaker containing filtered tapwater. Roots from diseased plants growing in nutrient solution were macerated in a Waring Blendor and the resulting suspension sprinkled with carborundum and stirred. The roots of the healthy plants were rubbed vigorously with this mixture and then the plants were transferred to pots containing sterilized soil. The plants were kept at high moisture for about 5 months and then cut back. None of these plants or their shoots became diseased in any respect after $61 / 2$ months. An equal number of healthy controls planted in sterilized soil also failed to develop symptoms of chlorotic streak.

\section{DISCUSSION}

The results of the study on soil transmission of chlorotic streak are in agreement with the findings of Antoine in Mauritius. The tests on soil transmission carried out in Puerto Rico were carefully controlled and it is most unlikely that any other agent not brought in with the unsterilized field soil was responsible for the cases of disease.

It seems likely that, under field conditions in Puerto Rico, the causal agent of the chlorotic-streak disease of sugarcane is transmitted mainly if not solely from the roots of affected to those of healthy plants through the soil. The available evidence suggests that high soil moisture is extremely 
important not only for the expression of the symptoms of the disease, but for the spread of its causal agent. At present, the prevailing theory is that this malady of sugarcane is caused by a virus.

While the leafhopper Draeculacephala portola Ball was reported by Abbott and Ingram (2) to be the vector of chlorotic streak in the State of Louisiana, so far as is known, others have not made successful studies to confirm or disprove these findings of Abbott and Ingram. Although the available scientific evidence strongly indicates that a virus is responsible for this disturbance, it seems reasonable not to disregard the seemingly remote possibility that it might be caused by another entity.

With respect to this, Carpenter (10) in Hawaii reported evidence that a Chytrid-like organism was in strict association with the tissues of affected sugarcane plants. Abbott and Sass (3), working in Louisiana, also observed the bodies that Carpenter interpreted as stages of the life cycle of a Chytrid, in the tissues of affected plants. However, these last workers believed that the various bodies exhibiting some degree of structural organization were probably the metabolic products of the affected plants rather than etiologic agents.

The fact that the causal agent of the chlorotic-streak disease is soil-transmitted would not necessarily exclude a virus as the possible entity responsible for this malady since other viruses have been found to be transmitted through the soil. Bawden (5) listed the causal agents of tobacco mosaic, wheat mosaics, lettuce big-vein, and tobaceo necrosis as belonging to this group of soil-borne viruses. According to him, the stability of tobacco mosaic is such that it would be expected to remain infective in the soil for long periods. The other viruses in this group, and which lose their infectivity more rapidly, are believed by Bawden to have some active phase of their existence in the soil.

The case of lettuce big-vein is somewhat different since, in 1958, Grogan, el al. (11), presented evidence that the big-vein disease of lettuce was intimately associated with infection of roots by the fungus Olpidium brassicae (Wor.) Dang. These investigators believed that there is a possibility that lettuce big-vein may be caused by a virus that is transmitted by Olpidium, but favored the theory that the symptoms result from a substance produced by the fungus and which is translocated to the leaves. The viruses that cause wheat mosaies were believed by McKinney (16) to be capable of overseasoning in the soil. In 1959 Walkinshaw and Larson (18) demonstrated that the corky ringspot disease of potatoes was soil-borne.

As to the possibility that nematodes might be involved in the spread of chlorotic streak in sugarcane, the writer's belief is that this could occur since nematodes have already been shown to be capable of acting as vectors of other plant viruses. For example, in 1958 Hewitt, Raski, and Gobeen 
(15) presented evidence that the dagger nematode, Xiphinema index, was the vector of the grapevine fanleaf virus. This seems to be the first report in the literature implicating a nematode as vector of a plant virus. Recently Harrison and Cadman (12) in England demonstrated that a species of Xiphinema related to or identical with Xiphinema diversicaudatum was responsible for the spread of Arabis mosaic virus. It seems likely that many other plant viruses will also be shown to be transmitted by nematodes. Work is being carried on in Puerto Rico to obtain further information on the spread of the causal agent of the chlorotic-streak disease through the soil, and further studies are in progress on the possible role played by nematodes with respect to this disease.

From studies herein reported it is known for the first time that Napier grass is definitely a host for the causal agent of the chlorotic-streak disease. The ecological conditions which favor the expression of symptoms and the spread of the disease in this host seem to be the same as for sugarcane. If the soils should become contaminated for any length of time with the agent that causes chlorotic streak then the disease will probably become more dangerous than it is at present.

\section{SUMMARY}

Transmission of the causal agent of the chlorotic-streak disease of sugarcane was effected when diseased and healthy plants were grown together in white quartz sand with ample moisture. Several healthy plants developed symptoms of chlorotic streak when they were grown in soil obtained from around and beneath severely affected plants from the field.

It was found that the causal agent of the chlorotic-streak disease of Napier grass is the same entity that causes the chlorotic-streak disease of sugarcane. Healthy sugarcane plants developed typical symptoms of chlorotic streak when grown together with affected Napier grass plants in nutrient solution.

Unsuccessful attempts were made to infect healthy sugarcane plants by mechanical inoculation of their roots with extracts obtained from roots of affected plants.

\section{RESUMEN}

El agente etiológico de la raya clorótica de la caña de azúcar se trasmitió de plantas enfermas a plantas sanas cuando éstas crecieron juntas, bajo condiciones controladas, en arena de cuarzo. Durante el curso del experimento esta arena se mantuvo siempre saturada de agua. También se infectaron plantas sanas que fueron sembradas en tierra que se obtuvo del área inmediata a las raíces de plantas enfermas que crecían en el campo.

Todas las indicaciones son de que el agente etiológico de la raya clorótica 
de la yerba Napier es el mismo que causa la raya clorótica en la caña de azúcar.

No se logró infectar plantas sanas de caña de azúcar cuando se frotaron sus raíces con extractos obtenidos de las raíces de las plantas afectadas.

\section{LITERATURE CITED}

1. Ablott, E. V., personal communication.

2. Abbott, E. V., and Ingram, J. W., Transmission of chlorotic streak of sugareane by the leafhopper Draeculacephala portola, Phylopath. 32 99-100, 1942.

3. Abbott, E. V., and Sass, J. E., Pathological Histology of sugareane affected with chlorotic streak, J. Agr. Res. 70(6) 201-7, 1945.

4. Antoine, R., Cane diseases: I, Chlorotic Streak, An. Rept. Mauritius Sugar Ind. Res. Inst. 53-57, 1957.

5. Bawden, F. C., Plant Viruses and Virus Diseases, Chron. Botanica Co., Waltham, Mass. 3d. ed., 335 pp., 1950.

6. Bird, J., Cibes, H., and Tió, M. A., Transmission of the Causal Agent of the Chlorotic-Streak Disease of Sugarcane through the Roots of Plants Grown in Nutrient Solution, Agr. Exp. Sta., Univ. P.R., Tech. Paper 27, 1958.

7. Boneta, E., personal communication.

8. Bruehl, G. W., Chlorotic-streak disease of Pennisetum purpureum, USDA Plant Dis. Reptr. 37 34-5, 1953.

9. Bruehl, G. W., and Boneta, E., A chlorotic-streak disease of Merker grass (Pennise(um purpureum), J. Agr. Univ. P.R. 39(4) 190-7, 1955.

10. Carpenter, C. W., A Chytrid in relation to chlorotic-streak disense of sugarcane, Hawaiian Planters Rec. 44 19-33, 1940.

11. Grogan, R. G., Zink, F. W., Hewitt, Wm. B., and Kimble, K. A., The association of Olpidium with the big-vein disease of lettuce, Phytopath. 48 292-7, 1958.

12. Harrison, B. D., and Cadman, C. H., Role of a dagger nematode (Xiphinema sp.) in outbreaks of plant diseases caused by Arahis mosaic virus, Nature 184(4699) 1624-6, 1959.

13. Hawaiian Sugar Planters' Association, Rept. of Exp. Sta. Committee, 1949.

14. Hawaiian Sugar Planters' Association, Rept. of Exp. Sta. Committee, 1957.

15. Hewitt, Wm. B., Raski, D. J., and Goheen, A. C., Nematode vector of soil-borne fanleaf virus of grapevines, Phytopath. 48 587-94, 1958.

16. McKinney, H. H., Soil-borne wheat mosaic viruses in the Great Plains, USDA Plant Dis. Reptr. 37 24-6, 1953.

17. Sturgess, O. W., Transmission of chlorotic streak, Cane Growers Quart. Bul. 23(2) $42-4,1959$.

18. Walkinshaw, C. H., and Larson, R. H., Corky Ringspot of Potato, a Soil-Borne Virus Disease, Univ. of Wis. Res. Bul. 217, 1950. 